\title{
Cell Death and Cavitation: The Beginning of Organogenesis
}

\author{
Li Xiao* and Takeki Tsutsui \\ Department of Pharmacology, The Nippon Dental University School of Life Dentistry at Tokyo, Japan
}

During embryonic development, cell death and the control of cell survival play major roles for the formation of various organs. In the solid embryonic structures, such as morula and primordiums, starvation and hypoxia cause central cell death [1]. Dying cells express the "eat-me" signal and are cleaned up by the neighbor cells through autophagy [2,3]. As a result, a lumen or cavity was created that also named cavitation or lumenation. The lumens or caves not only bring nutrition and oxygen for the surviving cells, but also deliver signals for differentiation. Under appropriate conditions created by the cavitation, the surviving cells differentiated into functional mature cells and then form tissues and organs [4-7] (Figure 1).

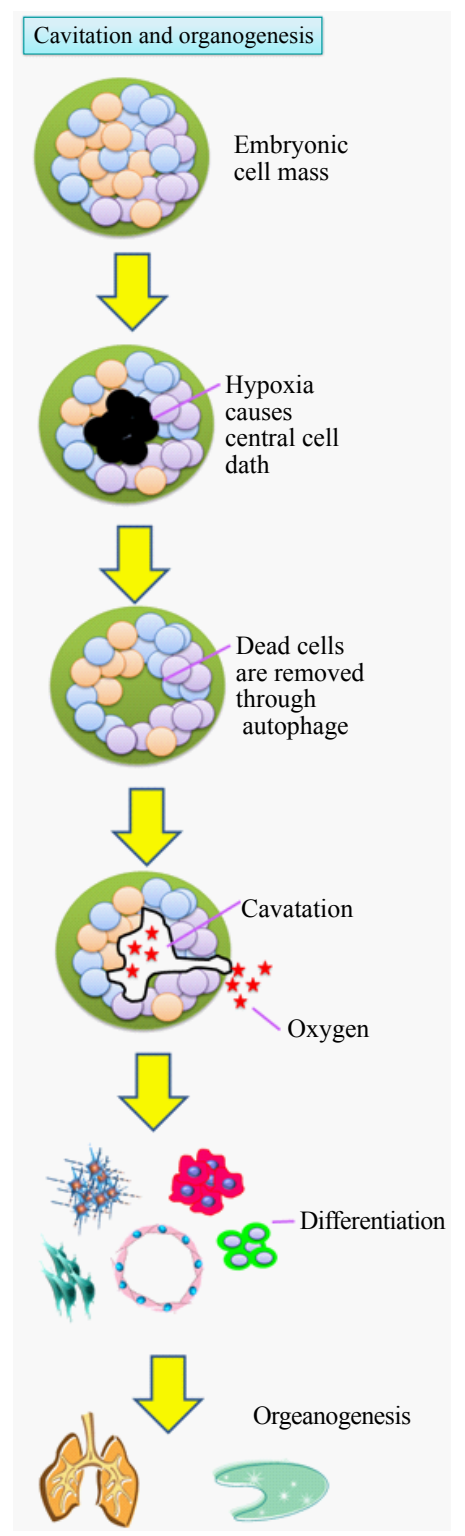

Figure 1: Cavitation and hollow organ formation.
For tissue engineering of hollow organs, such as lungs, kidneys and intestines, it is important to represent the above-mentioned process. Embryonic stem (ES) cells and induced pluripotent stem (iPS) cells have been wildly used to study cavitation and embryonic development due to their ability to forming embryoid bodies (EBs). Early in 1977, Martin et al. [4] described how to producing and culturing EBs to study embyogenesis. In 1999, Coucouvanis and Martin [8] reported that EBs in vitro could represent the process of cavitation, and signaling for death and survival is the underline mechanism. In 2007, Qu et al. [2] demonstrated that autophagy plays an important role in embryonic cavitation. Embryoid bodies (EBs) derived from cells lacking the autophagy genes fail to cavitation. A recent study showed that after straightly controlled the process of differentiation, human iPS cell-derived EBs were differentiated into intestinal tissue in vitro [9]. However, it remains a major challenge to represent the formation of more complicated organs, such as lung and kidney in vitro. To achieve the in vitro organogenesis of lung and kidney, three factors are considered the main stratagem. 1) Cell source. For the in vitro organogenesis, cells must have the ability to form EBs which offers the potential to differentiate into functional mature cells. ES and iPS cells are good cell source for so as we described before. However, because different cell lines of ES and iPS cells show different characters, to find the right one it needs carefully screen. 2) Three-dimensional culture systems which have the hypoxia microenvironment that can cause cell death and induce cavitation. Three-dimensional culture systems, such as spheroid represents a unique opportunity to reflect in vivo situations of organogenesis. For example, cancer cell- derived spheroid models not only displayed in vivo anti-tumor drug responses but also exhibited numerous pathophysiological features of tumor formation [10-12]. Culture scaffold, such as collagen gel, matrigel, hydrogel and so on also provide $3 \mathrm{D}$ environment in vitro therefor can be used for the in vitro culture. 2) Appropriate molecules stimulation. To drive the surviving cells towards functional mature cells, molecules for cavitation, such as BMPs, Bnip3 and AIF; and molecules for differentiation are necessary. 3) Supply of nutrition and neural stimulation. As the in vivo organs all have the network of blood vessel and neuron, the in vitro culture system must also offer the similar networks which requires co-culture with endothelial or neural progenitors.

Representing the in vivo cavitation and organogenesis is not easy, with the bioengineering technic and the new findings for embyogenesis and development, it would not be far.

*Corresponding author: Li Xiao, Department of Pharmacology, The Nippon Dental University School of Life Dentistry at Tokyo, 1-9-20 Fujimi, Chiyoda-ku Tokyo 102-8159, Japan, Tel: +81-3-3261-8772; Fax: +81-3-3264-8399; E-mail: xiaoli@tky.ndu.ac.jp

Received April 26, 2013; Accepted April 27, 2013; Published April 30, 2013

Citation: Xiao L, Tsutsui T (2013) Cell Death and Cavitation: The Beginning of Organogenesis. J Tissue Sci Eng 4: e122. doi:10.4172/2157-7552.1000e122

Copyright: $\odot 2013$ Xiao L, et al. This is an open-access article distributed under the terms of the Creative Commons Attribution License, which permits unrestricted use, distribution, and reproduction in any medium, provided the original author and source are credited. 
Citation: Xiao L, Tsutsui T (2013) Cell Death and Cavitation: The Beginning of Organogenesis. J Tissue Sci Eng 4: e122. doi:10.4172/21577552.1000 e122

\section{References}

1. Qi Y, Tian X, Liu J, Han Y, Graham AM, et al. (2012) Bnip3 and AIF cooperate to induce apoptosis and cavitation during epithelial morphogenesis. J Cell Bio 198: 103-114.

2. Qu X, Zou Z, Sun Q, Luby-Phelps K, Cheng P, et al. (2007) Autophagy genedependent clearance of apoptotic cells during embryonic development. Cell 128: 931-946.

3. Tra T, Gong L, Kao LP, Li XL, Grandela C, et al. (2011) Autophagy in human embryonic stem cells. PLoS One 6: e27485.

4. Martin GR, Wiley LM, Damjanov I (1977) The development of cystic embryoid bodies in vitro from clonal teratocarcinoma stem cells. Dev Biol 61: 230-244.

5. Saunders JW Jr (1966) Death in embryonic systems. Science 154: 604-612.

6. Ameisen JC (2002) On the origin, evolution, and nature of programmed cell death: a timeline of four billion years. Cell Death Differ 9: 367-393.
7. Guerrero I, Ruiz i Altaba A (2003) Development. Longing for ligand: hedgehog, patched, and cell death. Science 301: 774-776.

8. Coucouvanis E, Martin GR (1999) BMP signaling plays a role in visceral endoderm differentiation and cavitation in the early mouse embryo. Development 126: 535-546.

9. Spence JR, Mayhew CN, Rankin SA, Kuhar MF, Vallance JE, et al. (2011) Directed differentiation of human pluripotent stem cells into intestinal tissue in vitro. Nature 470: 105-109.

10. Friedrich J, Ebner R, Kunz-Schughart LA (2007) Experimental anti-tumor therapy in 3-D: spheroids--old hat or new challenge? Int J Radiat Biol 83: 849871.

11. Bates RC, Edwards NS, Yates JD (2000) Spheroids and cell survival. Crit Rev Oncol Hematol 36: 61-74.

12. Desoize B, Gimonet D, Jardiller JC (1998) Cell culture as spheroids: an approach to multicellular resistance. Anticancer Res 18: 4147-4158. 